\title{
MODEL PEMBELAJARAN PROBLEM SOLVING DI PONDOK PESANTREN
}

\author{
Siti Hajah Khalifaturohma, Zahrotul Mufida \\ Universitas Islam Negeri (UIN) Sunan Ampel Surabaya, Indonesia \\ e-mail: sitihajahkhalifaturohma@gmail.com
}

\begin{abstract}
The Islamic Boarding School is the oldest education institution in Indonesia. It doesn't hold on firmly to the classical method. But. It also follows the development. Until the emergence terminology of modern Islamic Boarding School. Including It's learning model which has followed to era development. But. It still maintains the Islamic Boarding School's values. One is problem solving earning model. The discussion this time will talk over related to problem solving as the authentic concept and tried to be compared with the Islamic Boarding school problem solving that's called bahtsul masail. The result of discussion indicates that bahtsul masa'il is more classic than problem solving. But. bahstul masa'il provides the problem solving more complex. It doesn't just based on the logical law. But also it must basically principled to $\mathrm{Al}$ Quran and Hadist and other instinbat methods.
\end{abstract}

Keywords: learning models, problem solving, pesantren

\section{PENDAHULUAN}

Secara genealogis, eksistensi pesantren ${ }^{1}$ berakar kuat pada masyarakat terutama di daerah Jawa Timur yang memiliki kuantitas pesantren terbanyak. Pesantren dibangun, dikembangkan dari, oleh dan untuk masyarakat itu sendiri. Artinya keberadaan pesantren tidak bisa lepas dari sejarah perkembangan serta sosial budaya pada suatu masyarakat, ${ }^{2}$ maka tidak heran jika pesantren dikemudian hari menjadi lembaga pendidikan yang diperhitungkan; bahkan dewasa ini pesantren memiliki kedudukan dan peran yang penting dalam upaya mencerdaskan bangsa. ${ }^{3}$

Pondok pesantren jika disandingkan dengan lembaga pendidikan yang pernah muncul di Indonesia, merupakan lembaga pendidikan tertua dan dianggap sebagai

\footnotetext{
${ }^{1}$ Pesantren adalah lembaga pendidikan Islam yang didalamnya terdapat seorang kiai (pendidik) yang mengajar dan mendidik para santri (peserta didik) dengan sarana masjid yang digunakan untuk menyelenggarakan pendidikan tersebut, serta didukung adanya pemondokan atau asrama sebagai tempat tinggal para santri. Abdul mujib dan Jusuf Mudzakkir, Ilmu Pendidikan Islam, (Jakarta: Kencana, 2008), , 234.

2 Ali wafa, "Problem Solving Berbasis Pesantren", Tarbiyatuna: Jurnal Pendidikan Islam, Vol. 08, No. 02 ( Agustus, 2015), 1

${ }^{3}$ Hariadi, Evolusi Pesantren Studi Kepemimpinan Kiai Berbasis Orientasi ESQ, (Yogyakarta: LKiS, 2015), 1.
} 
produk budaya Indonesia, dimulai sejak munculnya Islam di Nusantara. ${ }^{4}$ Pada awalnya pondok pesantren masih bersifat tradisional dan hanya mendalami ilmu-ilmu agama Islam sebagai pedoman hidup dan mengaplikasikannya dalam kehidupan bermasyarakat. Kiprah pondok pesantren tentu sangat dirasakan oleh masyarakat dalam kehidupan praktisnya sebab pondok pesantren menghadirkan sosok figur yang benar-benar ahli dalam bidang agama dan ilmu pengetahuan kemasyarakatan juga berakhlak mulia sehingga dapat dijadikan panutan dalam segala tindak tanduk berprilaku, ${ }^{5}$ selain itu tokoh tersebut juga menjadi jalan keluar untuk memecahkan masalah, masyarakat biasa menanyakan segala macam persoalan dan masalahnya kepada tokoh tadi untuk mendapatkan solusi.

Sistem pendidikan di pesantren artinya sarana yang berupa perangkat organisasi yang diciptakan untuk mencapai tujuan pendidikan di pondok pesantren. Karena pesantren merupakan subsistem pendidikan yang ada di Indonesia, maka tujuan pendidikan di pesantren secara umum juga mengacu kepada tujuan pendidikan nasional. ${ }^{6}$

Pada perkembangannya, pesantren sebagai lembaga pendidikan menghadirkan hal yang unik dan memiliki ciri-ciri dan karakteristik yang membedakan lembaga pendidikan ini dengan lembaga pendidikan lain. ${ }^{7}$ Pesantren dengan sejumlah kurikulum keilmuannya memberikan nuansa yang berbeda jika dibandingkan dengan tradisi pendidikan non pesantren. Tradisi keilmuan yang kuat dalam pesantren mampu memberikan bekal pada santri kelak setelah dinyatakan lulus memiliki kemampuan dalam menguasai kitab kuning ${ }^{8}$ (klasik) berbekal ilmu alat, seperti leksikografi, gramatika, dan mantiq, kemudian mendapat ijazah dari seorang kiai, untuk mengamalkan

\footnotetext{
${ }^{4}$ Kehadiran pesantren sangat erat kaitannya dengan sejarah masuknya Islam ke Indonesia. Oleh karena itu, pembahasan mengenai pesantren di tanah air tidak dapat dipisahkan dari pembahasan mengenai sejarah Islam, itu sendiri. Lihat: Azyurmardi Azra, Jaringan Ulama Timur Tengab dan Kepulauan Nusantara Abad XVII \& XVIII: Akar Pembaruan Islam Indonesia, (Jakarta: Prenada Media, 2005), 1-6.

${ }^{5}$ Syaiful Sagala, "Manajemen dan Kepemimpinan Pendidikan Pondok Pesantren", Jurnal Tarbiyah, Vol. 22, No. 01 (Juli-Desember, 2015), 6.

6 Ali Mustofa, "Perkembangan Kurikulum Pendidikan Agama Islam di Pesantren, Madrasah dan Sekolab” Jurnal Pikir: Jurnal Studi Pendidikan dan Hukum Islam, Vol 1, No,2. (September, 2015), 92.

${ }^{7}$ Jasa Ungguh Muliawan, Pendidikan Islam Integratif, (Yogyakarta: Pustaka Pelajar, 2005), 102.

8 Kitab yang menjelaskan hukum-hukum Islam yang bertuliskan huruf Arab gundul, dan biasa digunakan beberapa pesantren atau madrasah diniyah sebagai bahan pelajaran. PISS KTB, Tim Dakwah Pesantren, Tanya Jawab Agama Islam, (Jakarta: Daarul Hijrah Technology, 2015), 58
} 
ilmunya di tengah-tengah masyarakat. ${ }^{9}$ Ada banyak pengalaman yang terasa di pesantren untuk dapat dikembangkan di masyarakat. Dengan demikian, terasa penting menjaga tradisi keilmuan di pesantren yang sudah membumi di kalangan santri agar tidak usang, dan mampu menjadi bekal kelak di masyarakat. Sebagai produk intelektual pesantren, kitab kuning tidak saja ada pada masa awal perkembangan Nusantara, seperti yang diperkirakan para peneliti bahwa kitab kuning berbahasa Arab dan Jawi baru pada sekitar abad ke-16 M., serta menjadi kurikulum massal di pesantren sekitar abad 18-19 M. ketika banyak pelajar Indonesia belajar di Makkah. ${ }^{10}$

Menurut Sudjoko Prasodjo, pesantren sebagai lembaga pendidikan dan pengajaran agama, dalam pembelajarannya secara umum menggunakan cara nonklasikal dimana seorang kiai atau ustadz mengajarkan ilmu agama Islam kepada santri-santri berdasarkan kitab-kitab yang ditulis dalam bahasa arab oleh ulama abad pertengahan, dan para santri umumnya tinggal di asrama pesantren tersebut. ${ }^{11}$ Materi pembelajaran bermacam-macam, menurut Nurcholish Madjid ada empat macam pengetahuan yaitu fiqh, tasawnuf, tauhid, dan ilmu nabwu-sharraf..$^{2}$ Sedang Zamakhsyari Dhofier, memberikan pandangan melengkapi pandangan di atas yakni ada delapan pengetahuan pesantren, yaitu nabwu dan sharraf, fiqh, ushul fiqh, hadits, tafsir, taubid, tasawwuf dan etika, serta cabang ilmu lainnya seperti tarikh dan balaghah. ${ }^{13}$. Ahmad Baso, tanpa membedakan ilmu agama dan umum dengan mengelompokkan pengetahuan pesantren menjadi empat belas cabang ilmu. ${ }^{14}$ Kategori ilmu-ilmu pengetahuan yang merupakan lingkup kutub al-mu'tabarah, yaitu: 1) Ilmu ushổ (tanhid) dan ilmu kalam, 2) Ilmu fiqh dan ushul fiqh (termasuk hukum dan undang-undang), 3) Ilmu tafsir dan ilmu hadits, 4) Ilmu tasammuf dan ilmu etika (akhlaq), 5) Ilmu bahasa dan tata bahasa (ilmu nabwu, ilmu sharraf, pengetahuan bahasa-bahasa Nusantara dan leksiografi), 6) ilmu balaghah dan ilmu manthiq. Sedangkan untuk kategori pengetahuan umum meliputi: 1) Ilmu pertanian, 2) Ilmu kedokteran, 3) Ilmu astronomi, ilmu falak, dan astronomi,

9 Mustajab, Masa Depan Pesantren: Telaah Atas Model Kepemimpinan dan Manajemen, Pesantren Salaf, (Yogyakarta: LKiS, 2015), 123.

10 Affandi Mochtar, Membedah Diskursus Pendidikan Islam, (Ciputat: Kalimah, 2001), 39-40.

${ }^{11}$ Soedjoko Prasojo, Profil Pesantren, (Jakarta: LP3ES, 1978), 61

${ }^{12}$ Nurcholish Madjid, Bilik-Bilik Pesantren: Sebuah Potret Perjalanan, (Jakarta: Dian Rakyat, 1997), 31.

${ }^{13}$ Nurcholish Madjid, Bilik-Bilik Pesantren, 50.

14 Ahmad Baso, Pesantren Studies, Buku II; Kosmopolitanisme Peradaban Kaum Santri di Masa Kolonial, Juz. Pertama / 2a; Pesantren, Jaringan pengetahuan dan Karakter Kosmopolitan-kebangsaannya, vol.1, Jakarta : Pustaka Afid, 2012), 278. 
4) Matematika dan aljabar, 5) Ilmu teknik, 6) Ilmu bumi, ilmu alam dan ilmu biologi, 7) Ilmu syajarah, dan 8) Ilmu-ilmu sosial (ilmu politik, ilmu tata negara, dan ilmu ekonomi).

Kemudian dalam pesantren, tradisi akademik santri di pesantren merupakan satu bentuk proses pembelajaran yang tuntas, yang dapat menampilkan satu sosok lulusan pesantren yang berwawasan luas, berkepribadian matang, dan berkemampuan tinggi dalam melakukan rekayasa sosial. ${ }^{15}$ Pengajaran kitab-kitab kuning tersebut oleh santri kiai dilakukan berbentuk sorogan, bandungan atau weton, halaqah dan kelas musyawarah.

Akan tetapi, pernyataan tentang proses pembelajaran tersebut tidak sepenuhnya benar. Sebab, dalam perkembangannya pesantren juga menyesuaikan diri dengan perkembangan zaman, terdapat didalamnya perubahan-perubahan untuk lebih baik dalam mendidik santri-santrinya, termasuk juga terkait proses pembelajaran itu tadi. Dewasa ini sudah banyak pesantren yang menerapkan pola pembelajaran modern dengan mengintrodusir metode-metode atau model- model yang sedang berkembang di masyarakat, sehingga dalam penyebutannya pun menjadi pesantren modern, dimana di dalamnya dapat ditemukan pola-pola atau model-model pembelajaran yang serupa dengan sekolah pada umumnya, yang salah satunya adalah model pembelajaran problem solving.

Oleh sebab itu pembahasan kali ini akan berfokus kepada model pembelajaran problem solving di pondok pesantren. Tujuannya adalah untuk mengupas sedikit banyak tentang praktik-praktik serta perbedaan dan keunikan model pembelajaran problem solving yang diterapkan dalam pesantren dan juga non pesantren.

Pembahasan problem solving menjadi menarik untuk dikaji, sebab dalam proses pembelajarannya berhubungan dengan kehidupan sehari-hari, sehingga dapat merangsang kemampuan intelektual dan daya pikir siswa, serta melatih membiasakan diri dalam menghadapi masalah dengan berpikir secara sistematis dan menghubungkannya dengan masalah-masalah lainnya. ${ }^{16}$ Kemudian bagaimana penerapan problem solving di pesantren jika dibandingkan dengan konsep umum

\footnotetext{
15 Mochtar, Membedab Diskursus, 8.

16 Yeni Dwi Kurino, "Problem Solving Dapat Meningkatkan Hasil Belajar Siswa Pada Materi Operasi Penjumlahan dan Pengurangan Bilangan Bulat Di Kelas V Sekolah Dasar", Jurnal Cakrawala Pendas, Vol. 04, No. 01 (Januari, 2018), 58.
} 
problem solving yang sudah dikemukakan tadi, itulah yang menjadi poin penting mengapa perlu adanya penilitian praktik model pembelajaran problem solving di pesantren.

Adapun metode penelitian yang digunakan dalam penelitian ini adalah deskriptif komparatif dengan pendekatan kualitatif. Pendekatan kualitatif digunakan untuk menganalisis praktik model pembelajaran problem solving di pesantren dan non pesantren. Penelitian ini bersifat membandingkan keberadaan suatu variabel atau lebih pada dua sampel atau lebih sampel yang berbeda, ${ }^{17}$ pada penilitian ini terdapat dua variabel yaitu praktik model pembelajaran problem solving di pesantren dan non pesantren.

\section{PEMBAHASAN.}

\section{A. Model Pembelajaran Problem Solving}

Jika ditinjau dari pengertian kata per katanya maka problem merujuk pada situasi yang tidak jelas jalan pemecahannya yang mengkonfrontasikan individu atau kelompok untuk menemukan jawaban, dengan kata lain problem itu merupakan suatu kondisi yang menuntut untuk dihadirkannya suatu solusi. ${ }^{18}$ Sedangkan problem solving adalah upaya individu atau kelompok untuk menemukan jawaban berdasarkan pengetahuan, pemahaman, ketrampilan yang telah dimiliki sebelumnya dalam rangka memenuhi tuntutan situasi yang tak lumrah tersebut, yang berarti problem solving itu lebih menekankan kepada langkah-langkah sistematis dan terstruktur untuk menemukan jalan keluar. ${ }^{19}$

Dalam ranah pendidikan, model pembelajaran problem solving adalah pembelajaran yang menggunakan metode dalam kegiatan belajar mengajar dengan memberikan berbagai masalah baik itu masalah pribadi atau perorangan maupun masalah kelompok agar dipecahkan sendiri atau secara bersama-sama. Dan tugas seorang guru dalam proses pembelajaran adalah memberikan kasus atau masalah

\footnotetext{
${ }^{17}$ Sugiyono, Metode Penelitian Kuantitatif, Kualitatif, dan R\&D, (Bandung: Alfabeta, 2012), 54.

${ }^{18}$ Wahyu Utomo, "Peningkatan Hasil Belajar IPA Materi Ciri-Ciri Makhluk Hidup Dengan4 Menggunakan Model Problem Solving Siswa Kelas III Madrasah Ibtidaiyah Negeri Jambangan Surabaya Tahun Pelajaran 2013-2014" (Skripsi - UIN Sunan Ampel Surabaya, Surabaya, 2014), 12.

${ }^{19}$ Stephen Krulik dan Rudnick, The New Sourcebook for teaching Reasoning and Problem Solving in Elementary School, (Boston: Temple University, 1995), 4.
} 
kepada peserta didik untuk diselesaikan atau dipecahkan. Dalam melaksanakan proses belajar mengajar dengan model problem solving dapat dilakukan melalui prosedur: ${ }^{20}$ (1) mengindentifikasi penyebab masalah, (2) mengkaji teori untuk mengatasi masalah atau menentukan solusi, (3) memilih dan menetapkan solusi yang paling tepat, (4) menyusun prosedur dalam mengatasi masalah berdasarkan teori yang telah dikaji.

Menurut Tan, pembelajaran problem solving merupakan inovasi dalam pembelajaran karena dalam PBM, kemampuan berpikir siswa betul-betul dioptimalisasikan melalui proses kerja kelompok atau tim yang sistematis, sehingga siswa dapat memberdayakan, mengasah, menguji, dan mengembangkan kemampuan berpikirnya secara berkesinambungan. Moffit juga mengemukakan hal yang senada bahwa pembelajaran berbasis masalah merupakan suatu pendekatan pembelajaran yang menggunakan masalah dunia nyata sebagai suatu konteks bagi siswa untuk belajar tentang berpikir kritis dan keterampilan pemecahan masalah serta untuk memperoleh pengetahuan dan konsep yang esensi dari materi pelajaran. ${ }^{21}$ Jika digambarkan dengan sederhana, siswa dihadirkan suatu konteks permasalahan yang aktual untuk kemudian dirangsang agar mencoba memecahkannya secara kritis.

Berdasarkan hal itu, model pembelajaran problem solving sebenarnya adalah model pembelajaran yang lebih menekankan daya nalar siswa, merangsang kreativitas siswa dalam hal pemecahan segala masalah yang dihadapinya. ${ }^{22}$ Pembelajaran problem solving mencoba memberikan pembiasaan kepada siswa untuk lebih terbiasa menghadapi suatu masalah dan secara mandiri dapat menyelesaikannya; dan jika itu harus dikerjakan secara berkelompok maka problem solving ini memberikan bekal kepada mereka untuk dapat bekerjasama dalam menghadapi dan menyelesaikan masalah tersebut.

\footnotetext{
${ }^{20}$ Widia Maya dan Endang Susiloningsih, Penerapan Model ASSURE Dengan Metode Problem Solving Untuk Meningkatkan Ketrampilan Berpikir Kritis, Jurnal Inovasi Pendidikan Kimia, Vol 9, No. 1, (2015), 1468-1477.

${ }^{21}$ Chatib Munif, Gurunya Manusia, (Bandung: Kaifa Mizan Pustaka, 2010), 11.

${ }^{22}$ Sulastri, "Penerapan Metode Problem Solving Untuk Meningkatkan Aktivitas dan Hasil Belajar Siswa Dalam Pembelajaran Pkn Di Kelas VIIIc SMP Negeri 2 Tolitoli”, Jurnal Kreatif Tadulako Online, Vol. 04, No. 06, 314.
} 
Tentu model pembelajaran semacam ini sangat mampu untuk mendorong perkembangan pola pikir siswa. Terampil dalam memecahkan masalah bukanlah perkara mudah, bahkan untuk peka dan menyadari tentang adanya suatu masalah pada kondisi tertentu juga bukanlah perkara mudah, seseorang perlu dibiasakan untuk dapat menyadari tentang hadirnya masalah dan mencoba untuk menyelesaikannya dengan solusi yang paling tepat. Dengan demikian, model pembelajaran problem solving sebenarnya adalah pembelajaran yang membekali siswa dalam bidang pengetahuan sekaligus juga keterampilan, sebab memang dalam penyelesaian masalah seseorang perlu mengedepankan pemikiran yang logis serta keaktifan psikomotornya. Bahkan, jika problem solving ini diseting dalam model kelompok, dalam artian siswa diminta untuk bekerjasama dengan temannya, maka kompetensi sosial siswa juga dapat tergali.

Jika memang demikian adanya, maka problem solving tentu akan memberikan suasana pembelajaran yang tidak monoton dan pasif, bahkan problem solving juga akan melahirkan suasana pembelajaran yang sangat kreatif; sebab pada masing-masing masalah yang dihadirkan tentu memiliki penyelesaian masalah yang berbeda, masalah satu berbeda dengan masalah lainnya dalam hal solusinya. Sehingga, kondisi pembelajaran problem solving akan selalu menghadirkan sesuatu yang baru untuk siswa, suatu penemuan dan pengalaman berbeda disetiap masalah yang dihadirkan kepadanya. Ini tentu akan sangat positif untuk meningkatkan minat belajar siswa.

Ada hal menarik dari model pembelajaran problem solving ini, yaitu keterlibatan orang dewasa dimana dalam hal ini adalah guru itu sendiri. ${ }^{23}$ Siswa tidak dibiarkan begitu saja dalam hal menyelesaikan masalah, tapi juga mendapat pantauan dari guru itu sendiri dan bimbingan darinya, sehingga hal demikian dapat memberikan pengalaman berarti kepada siswa untuk terbiasa dengan pola pikir yang lebih kompleks sebagaimana dihadirkan oleh orang dewasa.

Sedemikian cakupan dari model pembelajaran problem solving, maka penilaian atau evaluasi terhadap model pembelajaran ini juga harus

${ }^{23}$ Wahyu Utomo, Peningkatan Hasil Belajar IPA ,15. 
komprehensif. ${ }^{24}$ Model pembelajaran ini tidak cukup hanya mengandalkan tes tulis saja, sebab yang dituntut untuk muncul dalam pembelajaran ini antara lain adalah pola pikir siswa, perfomen siswa dalam memecahkan masalah, termasuk juga kerjasama; dengan demikian, teknik-teknik penilaian yang akan muncul dalam pembelajaran ini bisa sangat beragam, bisa tes tulis dengan segala macam bentuknya, kemudian performen, penilaian jurnal, observasi, penilaian antar teman, penilaian diri sendiri, dan lain sebagainya.

\section{B. Praktik-praktik Model Pembelajaran di Pondok Pesantren}

Sebagaimana yang kita ketahui bahwa sistem pendidikan di pondok pesantren cenderung menggunakan sistem tradisional, yang dalam penerapannya dibangun dengan sederhana melalui model dan metode yang sederhana pula, namun dapat melahirkan hasil yang efektif dan produktif. ${ }^{25}$ Model dan metode yang sederhana ini tdak terlepas dari peran kiai, karena yang menyangkut, materi, waktu dan tempat pengajaran (kurikulum) tereletak pada kiai Sebab Otoritas kiai lebih dominan dalam pembelajaran di pondok pesantren. ${ }^{26}$ Diantara model pembelajaran yang biasa dilakukan di pondok pesantren, yaitu sorogan, bandungan atau wetonan, halaqah, musyawarah dan muthala' $a b^{27}$.

Menurut Zamarkasyari Dhofir, sorogan merupakan sistem pembelajaran dalam bentuk pengajian yang disampaikan kepada murid-murid secara individu. ${ }^{28}$ Sedangkan menurut Enung K Rukiati dan Fenti Hikmawati menyebut sorogan sebagai cara mengajar per kepala, yaitu setiap santri mendapat kesempatan tersendiri untuk memperoleh pelajaran secara langsung dari kiai. ${ }^{29} \mathrm{Hal}$ senada juga diungkapkan oleh Chirzin, sorogan mengharuskan santri menghadap guru secara

\footnotetext{
${ }^{24}$ Sudarman. "Problem Based Learning: Suatu Model Pembelajaran Untuk Mengembangkan dan Meningkatkan Kemampuan Memecahkan Masalah”, Jurnal Pendidikan Inovatif, Vol. 01, No. 02, 68-73.

${ }^{25}$ M. Nur Hasan, "Model Pembelajaran Berbasis Pondok Pesantren Dalam Membentuk Karakter Siswa (Penelitian pada Santri di Ponpes Roudhotut Tholibin Rembang)", Edukasi Jurnal Penelitian \& Artikel Pendidikan, Vol. 01, No. 02, 113.

26 Ibid, 114.

27 Ahmad Shiddiq, “Tradisi Akademik Pesantren”, Tadrîs, Vol. 10, No. 02, (Desember 2015), 227.

${ }^{28}$ Zamarkasyari dhofir, Tradisi Pesantren, Studi Tentang pandangan Hidup Kyai, (Jakarta: LP3ES, 1985), 28

${ }^{29}$ Enung K Rukiati dan Fenti Hikmawati, Sejarah Pendidikan Islam di Indonesia, (Bandung: Pustaka Setia, 2006), 106
} 
individu dengan membawa kitab yang akan dipelajarinya. ${ }^{30}$ Jadi pada prakteknya si santri diajari dan dibimbing bagaimana cara membaca.

Meskipun banyak orang menganggap sorogan sebagai model atau metode belajar yang klasik dan ketinggalan zaman, namun sampai saat ini sorogan masih dipertahankan dalam pengajaran pondok pesantren. Ini merupakan bukti bahwa sorogan memiliki kekhasan tersendiri sebagai bentuk pembelajaran yang cakupannya tidak hanya pada pencapain target keberhasilan belajar, melainkan pada proses pembelajaran melalui keaktifan belajar santri. ${ }^{31}$

Sedangkan bandongan atau wetonan merupakan model pembelajaran wetonan atau bandongan mengharuskan santri mengikuti pelajaran dengan duduk di sekeliling kiai. Kiai membacakan kitab yang dipelajari saat itu, santri menyimak kitab masing-masing dan membuat catatan. Pembelajaran ini dilakukan dalam rangka memenuhi kompetensi kognitif santri dan memperluas referensi keilmuwan mereka. ${ }^{32}$ Memang di dalam bandongan, hampir tidak pernah terjadi diskusi antara kiai dan para santri.

Selain itu ada juga istilah halaqash dan musyawarah. Pembelajaran halaqablebih kepada diskusi untuk memahami isi kitab, bukan untuk mempertanyakan kemungkinan benar salahnya apa-apa yang diajarkan dalam kitab, akan tetapi untuk memahami maksud yang dipelajari dari suatu kitab tersebut. ${ }^{33}$ Sedangkan model pembelajaran musyawarah yakni santri-kiai belajar bersama dalam bentuk seminar (tanya jawab), dan santri mempelajari kitab-kitab yang akan dibahas, hampir seluruhnya menggunakan bahasa Arab, dan merupakan latihan bagi santri untuk mencari argumentasi dalam sumber-sumber kitab-kitab klasik. ${ }^{34}$ Dalam praktiknya, model pembelajaran musyawarah juga menerapkan metode muthala'ah, bermakna meninjau kembali pemahamannya atas teks setelah bergumul dalam

${ }^{30}$ M.H. Chirzin, Agama, Ilmu, dan Pesantren, dalam M. Dawam Raharjo, Pesantren dan Pembaruan, (Jakarta: LP3ES, 1985), 88.

${ }^{31}$ Sugiati, "Implementasi Metode Sorogan pada Pembelajaran Tahsin dan Tahfidz Pondok Pesantren", Jurnal Qathruna, Vol. 03, No. 01 (Januari-Juni, 2016), 138.

${ }^{32}$ H. A. Idhoh Anas, "Kurikulum Dan Metodologi Pembelajaran Pesantren", Cendekia, Vol. 10 No. 1 (Juni 2012), 37-38.

33 Ahmad Shiddiq, Tradisi Akademik, 228.

${ }^{34}$ Imron Arifin, Kepemimpinjan Kyai Kasus Pondok Pesantren Tebuireng, (Malang: Kalimasahada Press, 1993), 31. 
kehidupan nyata di masyarakat, membaca, memahami arti teks, serta bahtsul masail dan pengkajian masalah-masalah. ${ }^{35}$

\section{ANALISIS}

\section{A. Praktik-praktik Model Pembelajaran Problem Solving di Pondok Pesantren}

Dalam dunia pesantren, model pembelajaran problem soving lebih dikenal dengan istilah babtsul masa'il. ${ }^{36}$ Babtsul masa'il merupakan metode pembelajaran yang mirip dengan metode diskusi/seminar. Dengan gambaran beberapa orang santri dengan jumlah tertentu membuat halaqah (kelompok/golongan) yang dipimpin langsung oleh ustadz/kiai, atau mungkin juga dipimpin oleh santri yang lebih senior untuk membahas dan mengkaji suatu persoalan yang ditentukan sebelumnya.

Sama halnya dengan problem solving, babtsul masail ini juga melibatkan peserta didik dalam proses pembelajaran yang aktif, kolaboratif, berpusat kepada peserta didik, yang mengembangkan kemampuan pemecahan masalah dan kemampuan belajar mandiri yang diperlukan untuk menghadapi tantangan dalam kehidupan dan karier, dalam lingkungan yang bertambah kompleks sekarang ini. pembelajaran berbasis masalah dapat pula dimulai dengan melakukan kerja kelompok antar peserta didik. Peserta didik menyelidiki sendiri, menemukan permasalahan, mengkonstruk pengetahuan mereka sendiri, dan mencapai puncaknya menghasilkan produk nyata sehingga masalah dapat terselesaikan dibawah petunjuk fasilitator (guru). ${ }^{37}$

Aktivitas bahtsul masail menempatkan santri bukan saja sebagai objek penelitian, melainkan subjek yang saling belajar. Biasanya, santri yang terlibat pada aktivitas ini adalah santri senior yang dianggap mampu menguasai materi kitab kuning. Karena objek kajiannya berkisar pada pendalaman kitab kuning yang

35 Anas, Kurikulum dan Metodologi, 38

${ }^{36}$ Ahmad Munjih Nasih dan Lilik Nur Kholidah, Metode Dan Teknik Pembelajaran Pendidikan Agama Islam, (Bandung: Rofila Aditman, 2009), 29

${ }^{37}$ Eko Andy Purnomo dan Venissa Dian Mawarsari, "Peningkatan Kemampuan Pemecahan Masalah Melalui Model Pembelajaran Ideal Problem Solving Berbasis Project Based Learning”, JKPM, VOL 01. NO. 01. (Januari, 2014), 26. 
dipelajarinya dengan tujuan agar para santri terlibat aktif dalam pembelajaran tanpa reserve materi yang diajarkan oleh gurunya melainkan subyek yang saling belajar. Dalam konteks ini dialektika pemikiran langsung secara produktif serta dapat menumbuhkan pemikiran-pemikiran yang kritis dan analitis bisa diharapkan. ${ }^{38}$

Al-Zarnuji menjelaskan bahwa santri harus melakukan bahtsul masa'il secara santun, terbuka, serta niat tulus untuk menyingkap kebenaran dan menutupi ketidaktahuan. Al-Zarnuji meyakinkan bahwa metode bahtsul masa'il lebih berhasil dari pada mengulang-ulang pelajaran secara personal. Dalam tradisi diskusi biasanya musyawarah masih ditekankan pada perbincangan gramatikal dari pada muata-muatan pada kandungan kitab. Meskipun para santri bermaksud mengkaji kandungan materinya, namun mereka kerap terjebak pada perdebatan panjang mengenai status gramatikal.

Hal ini justru akan mengeyampingkan perhatian utama pada kandungan dan isi kitab yang dikajinya. Diskusi akan lebih mengena apabila dalam pratiknya para santri mensinergikan persoalan-persoalan riil di lapangan dengan otoritas teks (dalam hal ini kitab kuning) yang dikajinya. Tujuan pelaksaan metode bahtsul masa’il adalah untuk melatih para santri dalam memecahkan masalah dengan menggunakan rujukan-rujukan yang jelas. Selain itu juga untuk melatih santri tentang cara berargumentasi dengan menggunakan nalar yang lurus.

Untuk melalukan pembelajaran dengan menggunakan metode bahtsul masa'il, kiai, ustadz biasanya mempertimbangkan ketentuan- ketentuan sebagai berikut: 1) Peserta musyawarah adalah para santri yang berada pada tingkat menengah atau tinggi. 2) Peserta musyawarah tidak memiliki perbedaan kemampuan yang mencolok. Ini dimaksudkan sebagai upaya untuk mengurangi kekurangan dalam musyawarah. 3) Topik atau persoalan (materi) yang dimusyawarahkan biasanya ditentukan terlebih dahulu oleh kiai atau ustadz pada pertemuan sebelumnya. 4) Pada beberapa pesantren yang memilki santri tingkat tinggi, musyawarah dapat dilakukan secara terjadwal sebagai latihan bagi para santri. ${ }^{39}$

\footnotetext{
${ }^{38}$ HM. Amin Haedari, Masa Depan Pesantren dalam Tantangan Moderenitas dan Tantangan Komplesitas Global (Jakarta: IRD Pess, 2004), 147.

${ }^{39}$ Muhammad Cholis, "Penerapan Bahtsul Masail Sebagai Problem Based Learning (PBL) Di Pondok Pesantren Sirojuth Tholibin Brabo, Tanggungharjo, Grobogan” (Skripsi - IAIN Surakarta, 2018), 23
} 
Kegiatan bahtsul masa’il diawali dengan penyajian masalah oleh nara sumber yang menguasai persoalan yang diangkat. Setelah nara sumber menyajikan masalah yang sebenarnya, moderator mempersilahkan peserta untuk membahas dan memberikan pendapatnya disertai dengan argumen-argumennya masing-masing, dimana setiap pendapat harus dilengkapi dengan argumen dari pendapat lain. Argumen yang diutarakan diambil dari kitab-kitab kuning yang mereka pelajari. Diakhiri dengan pembahasan, kesimpulan akhir dan akan dirumuskan oleh tim perumus atau musohhih untuk kemudian disahkan oleh majlis tashih (majlis pengesahan). ${ }^{40}$

Langkah-langkah persiapan terpenting pada model pembelajaran ini adalah terlebih dahulu memberikan topik materi yang akan dimusyawarahkan. Pilihan topik itu sendiri amat menentukan di dalam musyawarah. Topik yang menarik umumnya mendapat respon yang baik dan memberikan dorongan kuat kepada para santri untuk belajar. Penentuan topik secara awal lebih dimaksudkan agar para peserta musyawarah dapat mempersiapkan dari jauh-jauh hari sebelum musyawarah itu dilaksanakan.

Kegiatan penilaian dilakukan oleh kiai atau ustadz selama kegiatan musyawarah itu berlangsung. Hal-hal yang menjadi perhatian adalah kualitas jawaban yang diberikan oleh santri yang meliputi kelogisan jawaban, ketepatan, dan kevalidan referensi (ibarat kitab yang dipelajari) yang disebutkan serta bahasa yang disampaikan mudah dipahami oleh peserta bahtsul masa'il, serta kualitas pertanyaan atau sanggahan yang dikemukakan.

Metode bahtsul masa'il mengacu pada pemecahan masalah dalam persoalan fiqih. Materi yang jadi persoalan bervariasi dan mencakup masalah masalah aktual itu dibahas bagaimana pandangan Islam terhadap masalah tersebut. ${ }^{41}$ Biasanya dalam masalah-masalah aktual itu dibahas bagaimana pandangan islam terhadap masalah tersebut. Dalam forum bahtsul masa'il ini para santri dilatih untuk bertukar pikiran. Dalam pelaksanannya para santri dengan bebas mengajukan pertanyaanpertanyaan atau pendapatnya.

\footnotetext{
${ }^{40}$ Jajat Burhanudin dan Dira Afriyanti, Mencetak Muslim Modern Peta Pendidikan Islam di Indonesia. (Jakarta: Raja Grafindo Persada, 2006), 85

${ }^{41}$ Haedari, Masa Depan Pesantren, 100
} 
Dengan demikian metode bahtsul masa'il ini lebih menitik beratkan pada kemampuan perseorangan didalam menganalisis dan memecahkan masalah suatu persoalan dengan argumen logika yang mengacu pada kitab-kitab tertentu. Melalui mekanisme ini para santri sejak dini dilatih untuk menghargai perbedaan pendapat. Dengan demikian diharapkan bahwa para santri bisa bersikap toleran terhadap pendapat orang lain, sejauh pendapat itu didukung dengan argumen-argumen yang kuat. Perbedaan pendapat dalam tingkat wacana ini pada gilirannya diharapkan dapat mempengaruhi sukap-sikap dan perilaku santri terhadap perbedaan yang ada dilingkungan sekitar mereka.

Antara bahtsul masa'il dengan model pembelajaran problem solving hampir tidak ada perbedaannya. Hal yang paling nyata terletak pada rujukan dasar materi yang dibahas oleh kedua model pembelajaran tersebut, jika itu problem solving subjek materi yang disajikan biasanya hanya berkisar pada disiplin ilmu yang didasarkan pada pemikiran logis dengan modal premis-premis yang membangun logika sebuah permasalahan, akan tetapi jika itu babtsul masa'il rujukan dasarnya dikembalikan tidak hanya kepada hukum logika namun lebih dari itu harus mengacu pada dua hukum dasar Islam.

Dengan demikian, problem solving lebih sempit cakupannya daripada babtsul masa’il yang diterapkan di pesantren. Problem solving hanya finish pada hukum logika sedangkan bahtsul masa'il hukum logika yang muncul masih harus dikaji kembali, dicarikan dalil yang merujuk pada sumber islam, dan jika tidak ada maka dilakukanlah metode-metode sebagaimana yang telah dilakukan oleh para ulama, seperti ijtihad, qowli, ilhaqi, manhaji dan lain sebagainya. Ijtihad merupakan upaya yang dilakukan untuk menggali hukum yang sudah ada pada zaman Rasulullah saw, sehingga dalam perkembangannya ijtihad dilakukan oleh para sahabat, tabi'in, sampai masa selanjutnya sampai sekarang ini. ${ }^{42}$ Sedangkan madzhab manhaji dilakukan dengan istinbath jama'i mengenai hal- hal yang tidak ditemukan aqwalnya dalam madzhab empat oleh para ahlinya. Madzhab qouli yaitu pengambilan hukum merujuk pada kitab- kitab klasik para ulama' terdahulu. Dan metode ilhaq merupakan analogi suatu masalah pada masalah yang sudah ada ketentuan

42 Abd Wafi Has, Ijtihad Sebagai Alat Pemecahan Masalah Umat Islam, Jurnal Episteme, Vol. 8, No. 1, (Juni 2013), 20. 
hukumnya dalam ibarah kitab klasik para ulama'. Dari beberapa metode tersebut menunjukkan bahwa penyelesaian masalah dalam babtsul masa'il sangat rinci dan membutuhkan ketelitian dalam memutuskan masalah.

Babtsul masa'il yang dilaksanakan di pesantren tidak hanya mengkaji permasalahan hukum Islam, tetapi seluruh masalah yang menimbulkan polemik di masyarakat juga di selesaikan. Misalkan terdapat problematika dalam bidang kesehatan, maka dalam kegiatan bahtsul masa'il tersebut akan mendatangkan para ahli dibidang kesehatan dalam memutuskan permasalahan, tidak hanya mengkaji dalam bidang agama saja, karena keputusan bahtsul masa'il harus terdapat unsur kemaslahatan.

\section{B. Kelebihan Model Pembelajaran Problem Solving di Pesantren}

Model pembelajaran problem solving di pesantren memberikan suasana yang berbeda jika dibandingkan dengan praktik-praktik model pembelajaran tradisional di pesantren seperti sorogan, bandongan, halaqah, musyawarah, dan lain sebagainya, termasuk problem solving non pesantren. Beberapa kelebihan praktik model pembelajaran problem solving di pesantren antara lain: (1) Dapat melatih para santri dalam mencari dasar atau dalil untuk menjawab problematika kontemporer serta membantu masyarakat dalam menemukan hukum dan solusi hukum dengan lebih cepat dan mudah, (2) Menjalin tali silaturrahmi antar pondok pesantren, disini event digelarnya praktek pembelajaran problem solving (babtsul masait) dimanfaatkan sebagai tempat untuk saling mengenal dan saling menyambung tali silaturrahmi berbagai pondok pesantren yang ada, (3) Sebagai tempat atau forum diskusi ilmiah, dengan adanya diskusi memberikan banyak hal yang penting bagi para santri. Dari diskusi ini para santri bisa menjadi tahu hal-hal yang sebelumnya mereka tidak mengerti atau sekedar tahu. Dan di dalamnya para santri bisa berbagi pendapat atau pengetahuan dengan para santri yang lainnya. Hal lain yang juga disukai dan diskusi melalui forum ini adalah kesetaraan posisi antara satu dengan yang lain karena forum diskusi tidak mendewakan siapa saja yang menjadi pembicara utama. Diskusi memberikan wadah bagi semua santri untuk memiliki peran yang sama pentingnya. Tidak peduli ia memiliki kemampuan lebih ataupun berkemampuan sedang, lebih tua atau lebih muda, semuanya berhak 
untuk ikut serta berkontribusi di dalamnya. Selama Ia paham dan memiliki informasi tentang satu hal maka ia berhak mengutarakan pendapat dan ilmu yang ia punya melalui forum diskusi yang diselenggarakan dalam babtsul masail. ${ }^{43}$

\section{KESIMPULAN}

Problem solving di pesantren mempunyai istilah yang berbeda yaitu bahtsul masa'il. Secara mendasar keduanya tidak jauh berbeda, sama-sama mengusung kerangka berfikir yang logis dan sistematis dalam memecahkan masalah. Akan tetapi, babtsul masa'il mempunyai ruang yang lebih luas dalam prosesnya, merujuk pada kitab-kitab klasik dan juga melibatkan dua sumber primer Islam yaitu dengan yaitu al-Qur'ān dan Hadis. Tidak hanya sampai disitu, apabila tidak ditemukan rujukannya dalam kedua sumber tadi maka untuk menyelesaikan permasalahan babtsul masa'il mengandalkan bangunan-bangunan logika yang telah dicontohkan oleh para ulama terdahulu, seperti seperti j̈tibad, qawli, ilhaqi, manhaji dan lain sebagainya.

\section{DAFTAR PUSTAKA}

A. Idhoh Anas, H, "Kurikulum Dan Metodologi Pembelajaran Pesantren", Cendekia, Vol. 10 No. 1. Juni 2012.

Amin Haedari, HM., Masa Depan Pesantren dalam Tantangan Moderenitas dan Tantangan Komplesitas Global, Jakarta: IRD Pess, 2004.

Andy Purnomo, Eko dan Venissa Dian Mawarsari, "Peningkatan Kemampuan Pemecahan Masalah Melalui Model Pembelajaran Ideal Problem Solving Berbasis Project Based Learning", JKPM, VOL 01. NO. 01. Januari, 2014.

Arifin, Imron, Kepemimpinjan Kyai Kasus Pondok Pesantren Tebuireng, Malang: Kalimasahada Press, 1993.

Azra, Azyurmardi, Jaringan Ulama Timur Tengah dan Kepulauan Nusantara Abad XVII \& XVIII: Akar Pembaruan Islam Indonesia, Jakarta: Prenada Media, 2005.

Baso, Ahmad, Pesantren Studies, Buku II; Kosmopolitanisme Peradaban Kaum Santri di Masa Kolonial, Juz Pertama/ $2 a$; Pesantren, Jaringan pengetahuan dan Karakter Kosmopolitankebangsaannya, vol.1, Jakarta : Pustaka Afid, 2012.

${ }^{43}$ Muhammad Cholis, Penerapan Bahtsul Nasail, 65-66. 
Burhanudin, Jajat dan Dira Afriyanti, Mencetak Muslim Modern Peta Pendidikan Islam Ddi Indonesia. Jakarta: Raja Grafindo Persada, 2006.

Cholis, Muhammad, "Penerapan Bahtsul Masail Sebagai Problem Based Learning (PBL) Di Pondok Pesantren Sirojuth Tholibin Brabo, Tanggungharjo, Grobogan" Skripsi - IAIN Surakarta, 2018.

Dhofir, Zamarkasyari, Tradisi Pesantren, Studi Tentang Pandangan Hidup Kyai, Jakarta: LP3ES, 1985.

Dwi Kurino, Yeni, "Problem Solving Dapat Meningkatkan Hasil Belajar Siswa Pada Materi Operasi Penjumlahan dan Pengurangan Bilangan Bulat Di Kelas V Sekolah Dasar", Jurnal Cakrawala Pendas, Vol. 04, No. 01. Januari, 2018.

H. Chirzin, M, Agama, Ilmu, dan Pesantren, dalam M. Dawam Raharjo, Pesantren dan Pembaruan, Jakarta: LP3ES, 1985.

Hariadi, Evolusi Pesantren Studi Kepemimpinan Kiai Berbasis Orientasi ESQ, Yogyakarta: LKiS, 2015.

K Rukiati, Enung dan Fenti Hikmawati, Sejarah Pendidikan Islam di Indonesia, Bandung: Pustaka Setia, 2006.

Krulik, Stephen dan Rudnick, The New Sourcebook for teaching Reasoning and Problem Solving in Elementary School, Boston: Temple University, 1995.

Madjid, Nurcholish, Bilik-Bilik Pesantren: Sebuah Potret Perjalanan, Jakarta: Dian Rakyat, 1997.

Maya, Widia dan Endang Susiloningsih, Penerapan Model ASSURE Dengan Metode Problem Solving Untuk Meningkatkan Ketrampilan Berpikir Kritis, Jurnal Inovasi Pendidikan Kimia, Vol 9, No. 1, 2015.

Mochtar, Affandi, Membedah Diskursus Pendidikan Islam, Ciputat: Kalimah, 2001.

Mujib, Abdul dan Jusuf Mudzakkir, Ilmu Pendidikan Islam, Jakarta: Kencana, 2008.

Munif, Chatib, Gurunya manusia, Bandung: Kaifa Mizan Pustaka, 2010.

Munjih Nasih, Ahmad dan Lilik Nur Kholidah, Metode Dan Teknik Pembelajaran Pendidikan Agama Islam, Bandung: Rofila Aditman, 2009

Mustajab, Masa Depan Pesantren: Telaah Atas Model Kepemimpinan dan Manajemen, Pesantren Salaf, Yogyakarta: LKiS, 2015. 
Mustofa, Ali, "Perkembangan Kurikulum Pendidikan Agama Islam di Pesantren, Madrasab dan Sekolab” Jurnal Pikir: Jurnal Studi Pendidikan dan Hukum Islam, Vol 1, No,2. September, 2015.

Nur Hasan, M. "Model Pembelajaran Berbasis Pondok Pesantren Dalam Membentuk Karakter Siswa (Penelitian pada Santri di Ponpes Roudhotut Tholibin Rembang)", Edukasi Jurnal Penelitian \& Artikel Pendidikan, Vol. 01, No. 02.

PISS KTB, Tim Dakwah Pesantren, Tanya Jawab Agama Islam, Jakarta: Daarul Hijrah Technology, 2015.

Prasojo, Soedjoko, Profil Pesantren, Jakarta: LP3ES, 1978.

Sagala, Syaiful, "Manajemen dan Kepemimpinan Pendidikan Pondok Pesantren", Jurnal Tarbiyah, Vol. 22, No. 01. Juli-Desember, 2015.

Shiddiq, Ahmad, “Tradisi Akademik Pesantren”, Tadrîs, Vol. 10, No. 02, Desember 2015.

Sudarman. "Problem Based Learning: Suatu Model Pembelajaran Untuk Mengembangkan dan Meningkatkan Kemampuan Memecahkan Masalah", Jurnal Pendidikan Inovatif, Vol. 01, No. 02, 68-73.

Sugiati, "Implementasi Metode Sorogan pada Pembelajaran Tahsin dan Tahfidz Pondok Pesantren”, Jurnal Qathruna, Vol. 03, No. 01. Januari-Juni, 2016.

Sugiyono, Metode Penelitian Kuantitatif, Kualitatif, dan RひD, Bandung: Alfabeta, 2012.

Sulastri, "Penerapan Metode Problem Solving Untuk Meningkatkan Aktivitas dan Hasil Belajar Siswa Dalam Pembelajaran Pkn Di Kelas VIIIc SMP Negeri 2 Tolitoli”, Jurnal Kreatif Tadulako Online, Vol. 04, No. 06.

Ungguh Muliawan, Jasa, Pendidikan Islam Integratif, Yogyakarta: Pustaka Pelajar, 2005.

Utomo, Wahyu, "Peningkatan Hasil Belajar IPA Materi Ciri-Ciri Makhluk Hidup Dengan 4 Menggunakan Model Problem Solving Siswa Kelas III Madrasah Ibtidaiyah Negeri Jambangan Surabaya Tahun Pelajaran 2013-2014”' (SkripsiUIN Sunan Ampel Surabaya, Surabaya, 2014), 12.

Wafa, Ali, "Problem Solving Berbasis Pesantren", Tarbiyatuna: Jurnal Pendidikan Islam, Vol. 08, No. 02 , Agustus, 2015

Wafi Has, Abd, Ijtihad Sebagai Alat Pemecahan Masalah Umat Islam, Jurnal Episteme, Vol. 8, No. 1, Juni 2013. 